\title{
ISO/TS 16949: analysis of the diffusion and current trends
}

\author{
F Franceschini*, M Galetto, D A Maisano, and L Mastrogiacomo \\ Dipartimento di Sistemi di Produzione ed Economia dell'Azienda, Politecnico di Torino, Torino, Italy
}

The manuscript was received on 6 May 2010 and was accepted after revision for publication on 19 July 2010.

DOI: $10.1177 / 2041297510394061$

\begin{abstract}
The automotive industry has always shown a particular interest in quality management systems, which resulted in the development of several different specific standards. As a result of this, by the mid-1980s, automotive suppliers were subject to numerous national and customer-specific regulations. The proliferation of these standards and the need to create a single reference model led to Technical Specification (TS) 16949, an International Organization for Standardization (ISO) technical specification aimed at representing a comprehensive quality management system for the global automotive industry. Since its early introduction, TS 16949 has encountered a certain success thanks to its feature of unifying and harmonizing the already existing standards. This paper studies the global evolution and diffusion of this technical specification, observing its impact on local economies. The findings are supported by empirical data.
\end{abstract}

Keywords: quality standards, quality system, ISO/TS 16949, standard diffusion, evolution trend, automotive

\section{INTRODUCTION}

The International Organization for Standardization (ISO) promulgates worldwide industrial and commercial standards. Its portfolio in 2010 comprised more than 18000 standards that provide practical solutions for every sector of economic activity and technology. Among these, the ISO 9000 family is the most wellknown and widely implemented standard ever [1-4]. It is used worldwide by large and small businesses and organizations, in public and private sectors, by manufacturers and service providers, and in all fields of activity [5].

Over time, various industry sectors have standardized their interpretation of the guidelines within their own marketplace to ensure the achievement of their specific requirements. Some examples are the AS9000, PS 9000, ISO/TS 16949, TL 9000, TickIT, and ISO 13485:2003 standards, respectively for the aerospace, pharmaceutical, automotive, telecommunication,

*Corresponding author: Dipartimento di Sistemi di Produzione, ed Economia dell'Azienda, Politecnico di Torino, Corso Duca degli Abruzzi 24, Torino 10129, Italy.

email: fiorenzo.franceschini@polito.it software, and medical industries. Among these, ISO/TS 16949 is certainly the most diffused and implemented. At the beginning of 2009, almost 40000 ISO/TS 16949 certificates had been issued in 81 different countries and economies [5]. Some explanations for such a diffusion of this as well as of other quality standards may be identified in the role of government directives, in the multinational enterprises requiring supplier adoption, and in the extensive adoption by trading partners and trading competitors $[\mathbf{2}, \mathbf{4}, \mathbf{7}-\mathbf{9}]$.

The aim of this paper is to look at the particular diffusion patterns the ISO/TS 16949 had within different countries. More specifically, the intention is to clarify whether the adoption of these standards has suffered local influences owing to customer regulations or particular economic market conditions. To this purpose, the national patterns of TS 16949 diffusion have been analysed for the most important countries.

The work is organized as follows. Section 2 focuses on the origin of TS 16949, analysing its major features and drivers of success. In section 3 the diffusion trend is analysed by comparing the number of TS 16949 certificates with automotive production and gross domestic product. Finally, results and future research perspectives are discussed. 


\section{ISO/TS 16949 FRAMEWORK}

ISO/TS 16949 is the first ISO 9000-based technical specification that represents a comprehensive quality management system (QMS) for the global automotive industry. Specifically, it identifies the quality system requirements for the design, development, production, installation, and servicing of automotive-related products.

The International Automotive Task Force (IATF) produced TS 16949 with the support of the Japanese Automobile Manufacturers Association (JAMA) and ISO Technical Committee 176 (TC 176) - i.e. the ISO committee that specifically deals with quality management standards. This standard was developed to satisfy a pressing need of the automotive suppliers, which - since the 1990s - were subject to a confusing mass of military, national, and customer standards. The first edition (ISO/TS 16949:1999) was extensively and periodically revised in line with the newest version of ISO 9000 package. The current edition (ISO/TS 16949:2009) contains the guidelines for the development of a global management system, pushing towards continuous improvement, defect prevention, and reduction of variability and waste in the supply chain (ISO, 2009b). As for ISO 9001, TS 16949 certification does not guarantee any quality of end products and services, it just certifies that formalized processes are being applied according to specific requirements defined by individual manufacturers.

In general, there are three reasons why companies seek ISO TS 16949 certification: (a) its use as a valuable marketing tool, (b) the implementation of a recognized and efficient system of quality management, and (c) the need to meet customer requirements.

\subsection{A marketing tool}

ISO/TS 16949:2009 contains the full text of ISO 9001:2008 and automotive industry-specific requirements. Researchers and practitioners are unanimous in recognizing that this kind of quality certification helps and eases business relations between companies, and represents an important marketing tool to develop, strengthen, and ease business contacts with national and international partners, customers, and suppliers [10]. Clougherty and Grajek [4] recognize three principal features stimulating business-tobusiness relations.

1. The certification offers a relatively low-cost signal of a firm's commitment to quality, reducing barriers between businesses. Companies and enterprises are proud to claim a documented quality system which is implemented and followed, ensuring that products are made to exacting specifications [11, 12]. In addition, the certification can strengthen the reliability image of suppliers, steering customer companies when they have to deal with multiple suppliers, and the attributes of suppliers are intangible $[4,15]$.

2. ISO quality certifications involve a commonlanguage that facilitates communication between businesses $[\mathbf{1}, \mathbf{4}, \mathbf{1 4}]$. Introducing a common procedural language to be used across organizations, the certification represents an efficient tool to communicate internal processes to customers and suppliers.

3. ISO quality certifications help reducing and sometimes settling organizational disputes [2]. By specifying the responsibilities involved with complex inter-organizational production, the certification can help clarify situations where faults are unintended and not attributable to opportunistic behaviour [15].

\subsection{A tool for internal improvement}

Although no specific study on TS 16949 certifications has been explicitly realized, there is evidence that ISO 9000 series certifications help to increase business performance especially for companies that are at the early stages of their quality journeys [16-23]. With their research, Pekovic and Galia [24] provide empirical findings that support the notion that quality certification improves innovation performance. The analyses performed by Escanciano et al. [25] found the presence of a positive relationship between a high technological level and the firm's advance towards total quality management (TQM). Other researches show statistically significant improvements after ISO 9000 series certification, concerning 'quality performance in production and on the reliability of the production system' and 'external quality performances' [26]. Furthermore, non-quality costs seem to diminish significantly after the certification.

\subsection{An important prerequisite}

The IATF is an 'ad hoc' group of automotive manufacturers and their respective trade associations. It was founded with the aim of developing a consensus regarding international fundamental quality system requirements, primarily for the participating companies' direct suppliers of production materials, product or service parts, or finishing services (e.g. heat treating, painting, and plating) [27]. IATF members currently include the following vehicle manufacturers: BMW Group, Chrysler LLC, Daimler AG, Fiat Group Automobiles, Ford Motor Company, General Motors Corporation (including Opel Vauxhall), PSA Peugeot-Citroen, Renault, Volkswagen AG, and the vehicle manufacturers' respective trade associations AIAG (US), ANFIA (Italy), FIEV (France), SMMT (UK), and VDA (Germany). 
In order to provide suppliers with a common reference framework, automotive manufacturers belonging to the IATF decided to adopt a group policy that requires ISO/TS 16949 certification from their suppliers. Some of the automotive manufacturers not belonging to the IATF also showed appreciation of the certification, even if, in some cases, it was not explicitly required from their suppliers. In general, 'there is a significant global consensus in the automotive sector on the fundamental quality requirements in TS 16949' [28].

\section{TS 16949 - WHERE ARE THEY GOING TO?}

This paper takes stock of TS 16949 certification, a few years after its introduction, exploring causes and consequences of its diffusion. In detail, the goal of the analysis is to provide answers to the following questions.

1. How will the market of TS 16949 certifications evolve? In which phase of the evolution is it and what will probably happen in the near future?

2. Why do suppliers seek certification? Is there a relation between the car producer's policies and the number of TS 169494 certificates issued in a given country?

3. What is the impact of the evolution of the number of certifications in the automotive sector on national economies?

\subsection{Method of analysis}

The analysis presented in this paper is based on the number of ISO/TS 16949 certificates issued in the period 2004-2008. Data come from the ISO Survey which annually collects and publishes information on the number of certificates issued, nation by nation [5]. It is noteworthy that the survey is related to the numbers of certificates, not to the numbers of sites covered by any certificate.

First, the global trends of evolution are presented, using a logistic model in order to forecast the future evolution pattern [29]. This model, which was originally proposed to describe bio-population evolution, demonstrated that it could give a good description of ISO 9000 evolutionary behaviour [30]. Section 3.2 gives an accurate description of the model as presented by Franceschini et al. [29].

Then the number of TS 16949 certificates is compared with the overall automotive production. These data are drawn from the OICA (Organisation Internationale des Constructeurs d'Automobiles) web database. This database contains world vehicle production statistics, obtained annually from national trade organizations, OICA members, or correspondents. The comparison between production and number of TS 16949 certificates allows any possible correlation to be highlighted.

Finally the growth pattern of TS 16949 certificates is compared with the GDP per capita evolution. Data regarding national GDP per capita come from the World Economic Outlook Database, published by the International Monetary Fund (IMF) [31].

\subsection{Logistic forecasting model}

Franceschini et al. [29] empirically showed that the ISO 9000 diffusion process is very close to the behaviour of the so-called logistic systems, first introduced by the Belgian mathematician Pierre Verhulst [32] to describe phenomena related to bio-population growths. The set of hypothesis considered by the predictive model are as follows:

(a) the model considers only the total number of certified enterprises, paying no attention to their specific dimension and to their commodity sector;

(b) the diffusion growth is influenced by national incentives, by the presence of local Governments' encouragement and by the number of certification bodies;

(c) there are not events or external interferences (for example, international/national regulatory/legislation changes) that can change the natural evolution of the so-called 'certus-population' (i.e. the ISO 9000 standard certified companies, hereinafter called 'certus-population').

Denoting by $N(t)$ the number of ISO 9000 standards-certified companies over time, the 'modified-logistic-curve' for a 'certus-population' is as follows [29]

$$
N(t)=\frac{N_{0} \cdot K}{N_{0}+\left(K-N_{0}\right) \mathrm{e}^{-r_{0} t}}-N_{0}
$$

where the parameters have the following meaning:

(a) $N(t)$ is the number of ISO 9000 standards-certified companies over time;

(b) $r_{0}$ is the population growth rate in the absence of intra-specific competition;

(c) $N_{0}$ represents the translation value to assure the condition $N(0)=0$;

(d) $N(\infty)=\left(K-N_{0}\right)$ is the certus-population saturation level, that is the total number of companies that will be interested in the certification process.

This model, which is also widely utilized to model the diffusion process of new technologies [33], was found to be suitable for the modelling of the evolution of 'certus-populations' during their rapid growth phase. As ISO/TS 16949 is a relatively new technical specification; this model has been chosen for the analysis of its evolution. 


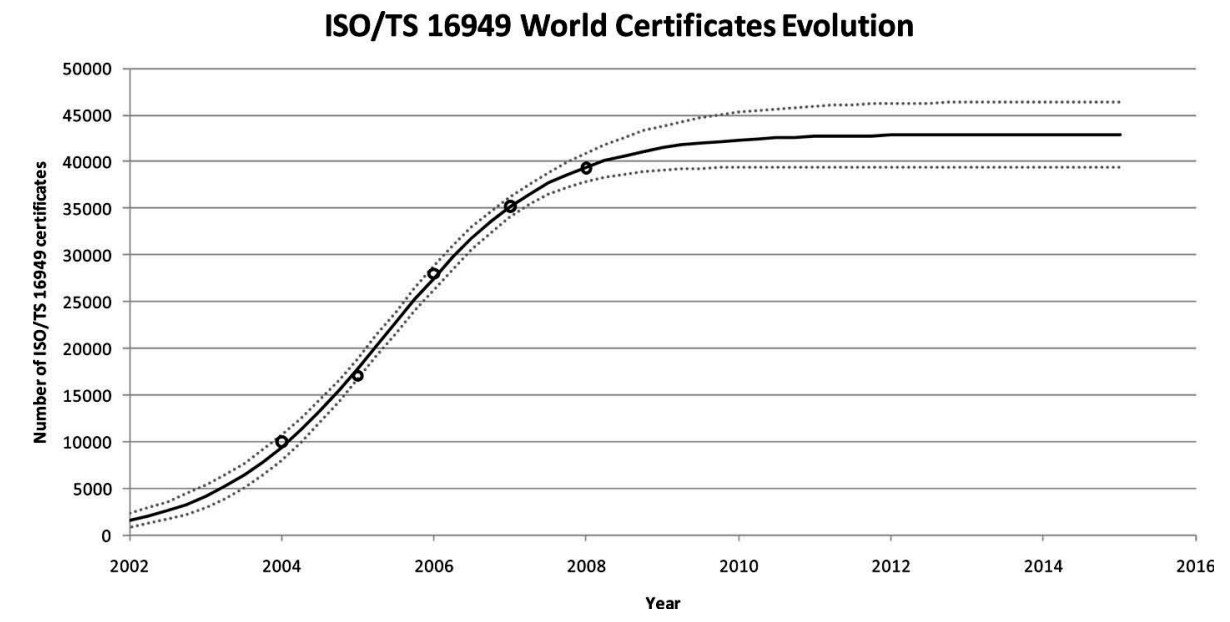

Fig. 1 ISO/TS 16949 world certificates evolution. The logistic model is plotted with a solid line while dotted lines define its 95 per cent confidence band. The number of certificates per year is plotted in small circles [5]

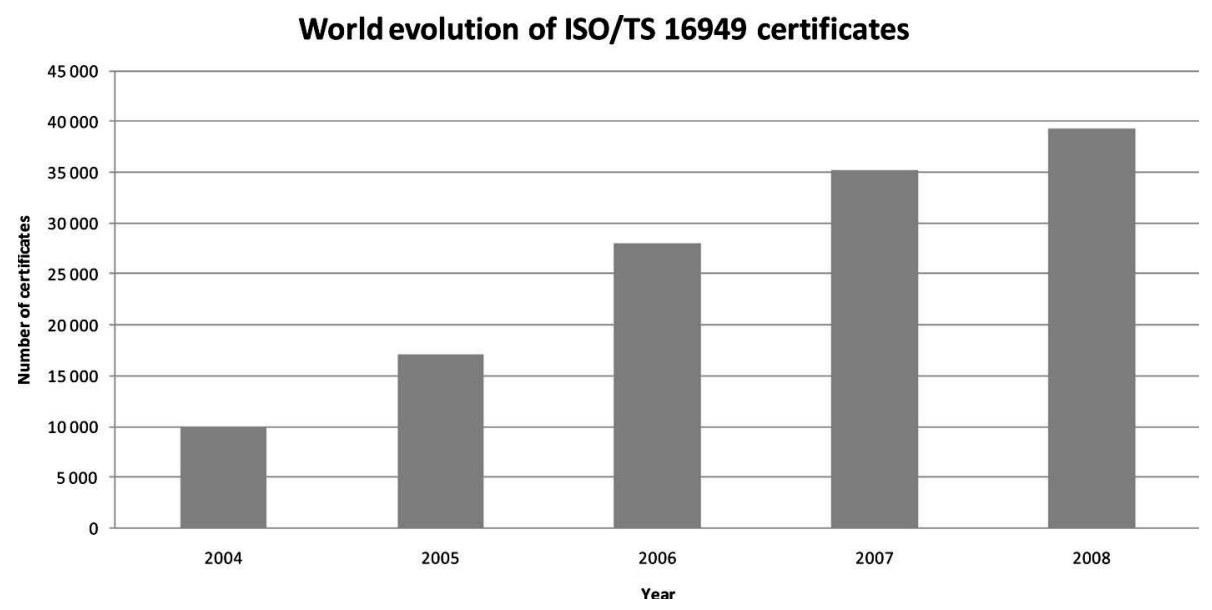

Fig. 2 ISO/TS 16949 certificates evolution [5]

As an example, Fig. 1 presents the ISO/TS 16949 world certificates evolution as fitted by the logistic model (solid line). In this case $N(t)$ is the number of ISO/TS 16949 certificates issued at time $t$.

\subsection{Evolution of ISO/TS certification}

The world growth in the number of ISO/TS 16949 certifications is flourishing. According to the 2009 ISO survey [5], the number of certifications seems to be constantly growing year by year (see Fig. 2 and Table 1 for more details).

Up to the end of December 2008, almost 40000 ISO/TS 16949 certificates had been issued in 81 countries and economies. The 2008 total represents an increase of $4122(+12$ per cent) compared with 2007 when the total was 35198 certificates in 81 countries and economies.

To understand how much space there is left for the certification market, it is necessary to estimate the number of automotive suppliers. The estimate is complicated by the fact that the supply chain is often very long and complex. Moreover, some suppliers may be shared by several manufacturers and they are sometimes owned by the same car makers. However, a rough estimate can be given by comparing the data published by some of the major car makers with their production volumes [34-37]. Projecting these data on world production volume, the number of direct and indirect automotive suppliers is found to be around 250000 . This means that the percentage of currently certified automotive suppliers is around 16 per cent of all suppliers.

From the above considerations it is clear that there is still a future for this type of certification. According to the logistic model proposed by Franceschini et al. [29] for ISO 9000 certification evolution, the phenomenon has not reached a saturation level yet. In detail, the number of TS 16949 certificates issued all around the world will probably increase by about 10 per cent by the end of 2012, settling around a value of about 43000 certificates (see Fig. 1). 
Table 1 Number of ISO/TS 16949 certificates per continent

\begin{tabular}{|c|c|c|c|c|c|c|}
\hline & 2004 & 2005 & 2006 & 2007 & 2008 & 2008 Growth \\
\hline Australia/New Zealand & $165(2 \%)$ & $50(0 \%)$ & $129(0 \%)$ & $181(1 \%)$ & $188(0 \%)$ & $3.9 \%$ \\
\hline Central and South America & $394(4 \%)$ & $734(4 \%)$ & $1270(3 \%)$ & $1383(4 \%)$ & $1454(4 \%)$ & $5.1 \%$ \\
\hline Africa/West Asia & $417(4 \%)$ & $1568(9 \%)$ & $2573(7 \%)$ & $3158(9 \%)$ & $3473(9 \%)$ & $10.0 \%$ \\
\hline North America & $4517(45 \%)$ & $4571(27 \%)$ & $5230(13 \%)$ & $5929(17 \%)$ & $5903(15 \%)$ & $-0.4 \%$ \\
\hline Europe & $3212(32 \%)$ & $6290(37 \%)$ & $8943(23 \%)$ & $10159(29 \%)$ & $10771(27 \%)$ & $6.0 \%$ \\
\hline Far East & $1314(13 \%)$ & $3834(22 \%)$ & $9854(25 \%)$ & $14388(41 \%)$ & $17531(47 \%)$ & $21.8 \%$ \\
\hline Total & 10019 & 17047 & 27999 & 35198 & 39320 & \\
\hline
\end{tabular}

\section{Regional Share in percent}

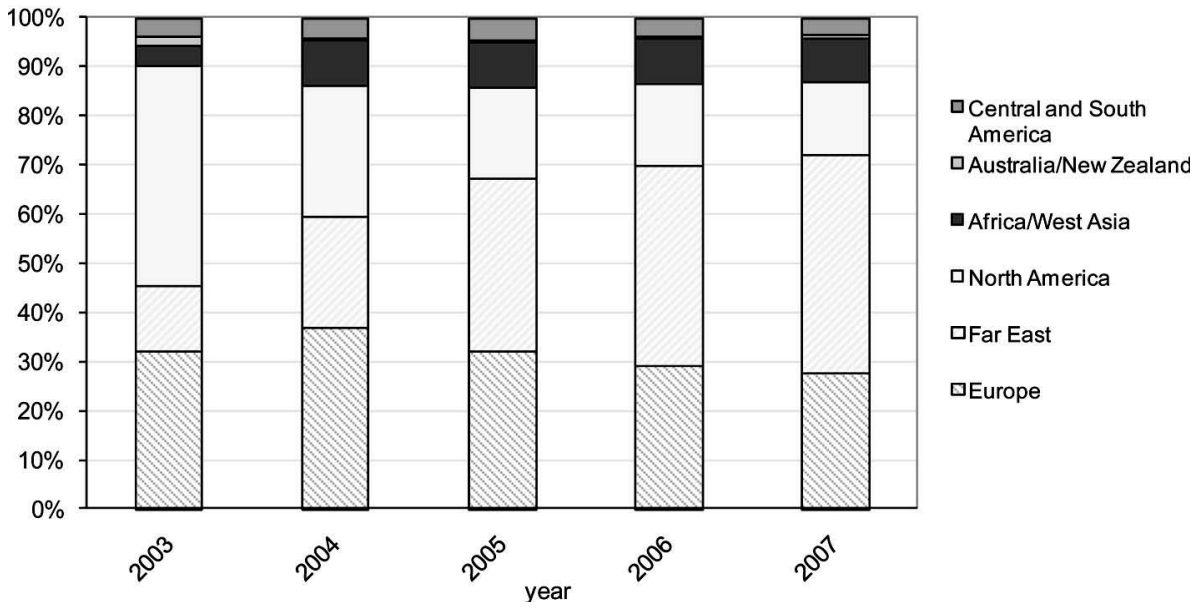

Fig. 3 Regional share of ISO/TS 16949 certificates [5]

Notwithstanding a global growth trend, it is interesting to notice how things are evolving: Europe is no longer the leading continent. The number of certificates issued in the Far East countries is experiencing an unparalleled growth and, since 2006, has significantly exceeded that of Europe (see Table 1 and Fig. 3). To date, this region holds about 45 per cent of all certificates issued, growing only in the last year to 21.8 per cent. The scenario that emerges is clear: the suppliers' market is gradually but inexorably moving towards the nations of the Far East. This is the result of the heavy investments that the major automobile manufacturers have made in those countries where low labour and production costs have ensured a steadily growing economy in recent years.

On the other hand, the North America position reveals a particular behaviour. Among all the continents, it is the only one in which the number of certificates in 2008 did not increase, having probably reached a saturation level. It has to be said that the natural dynamism of the North American market has never recognised ISO 9000 series certification as a distinguishing element in business competition [38]. Nevertheless, TS 16949 certification encountered a certain success from the introduction stage (4517 certifications issued in 2004), probably as a consequence of the tendency of the major automotive manufacturers (GM, Chrysler, and Ford) to push companies to pursue this kind of certification.

Analysing individual countries, data, China has the lion's share, holding more than half of the certificates issued in the Far East (see Table 2 and Fig. 4). Beyond China, other noteworthy countries are South Korea, India, and Japan, in which, during the last year of analysis, the number of certificates increased respectively by 9.4 per cent, 12 per cent, and 7.5 per cent. Among European countries, Italy and Germany are probably the most promising markets for TS 16949 certification.

\subsection{Number of certificates versus automotive production}

Despite strong incentive policies implemented by national governments, production of passenger cars and commercial vehicles has been in constant decline since 2008, owing to the global economic crisis of recent years. The year 2008 closed with a decline of -1.6 per cent for the segment of passenger cars and -10.84 per cent for the segment of commercial vehicles. The year 2009 was even worse, scoring respectively -1.26 per cent and -12.16 per cent in the two segments (see Fig. 5).

Automotive industry production is not evenly distributed among the different nations. In particular 


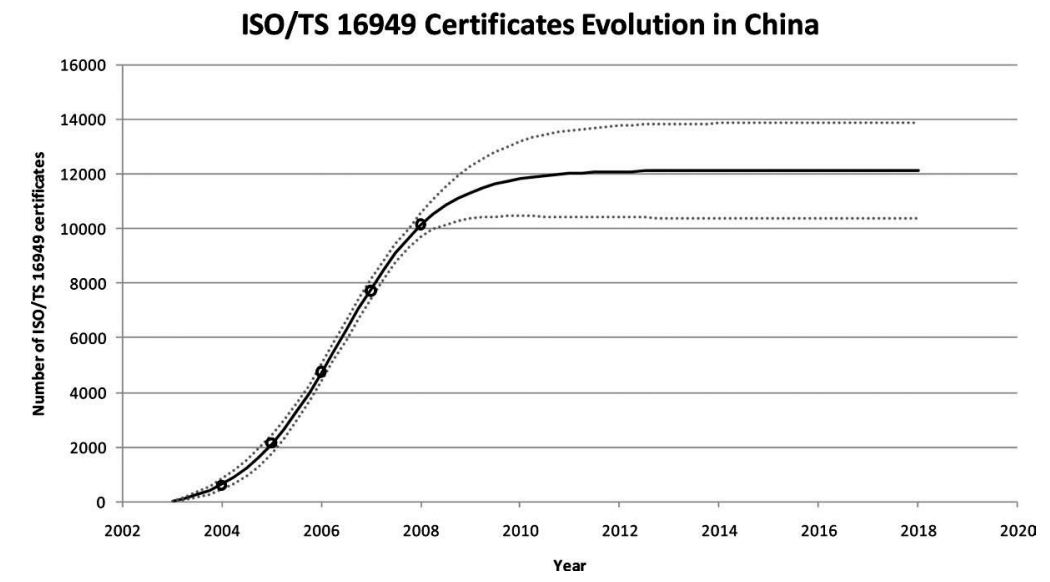

Fig. 4 ISO/TS 16949 certificates evolution forecast in China according to the forecasting model proposed by Franceschini et al. [29]. The logistic model is plotted with a solid line while dotted lines define its 95 per cent confidence band. The number of certificates per year is plotted in small circles [5]

Table 2 Number of ISO/TS 16949 certificates issued per country [5]

\begin{tabular}{|c|c|c|c|c|c|c|}
\hline \multirow[b]{2}{*}{ Nation } & \multicolumn{5}{|c|}{$\begin{array}{l}\text { Number of ISO/TS } \\
16949 \text { certificates }\end{array}$} & \multirow{2}{*}{$\begin{array}{l}2008 \\
\text { Growth }\end{array}$} \\
\hline & 2004 & 2005 & 2006 & 2007 & 2008 & \\
\hline China & 459 & 2151 & 4758 & 7732 & 10144 & $31.2 \%$ \\
\hline USA & 3693 & 3693 & 3852 & 4288 & 4239 & $-1.1 \%$ \\
\hline South Korea & 366 & 834 & 2621 & 3453 & 3779 & $9.4 \%$ \\
\hline Germany & 1043 & 2115 & 2763 & 3068 & 3243 & $5.7 \%$ \\
\hline India & 225 & 954 & 1588 & 2008 & 2248 & $12.0 \%$ \\
\hline Japan & 169 & 177 & 939 & 1106 & 1189 & $7.5 \%$ \\
\hline France & 89 & 854 & 1127 & 1165 & 1183 & $1.5 \%$ \\
\hline Italy & 173 & 312 & 935 & 1024 & 1088 & $6.3 \%$ \\
\hline Brazil & 299 & 480 & 846 & 972 & 1037 & $6.7 \%$ \\
\hline Mexico & 566 & 495 & 758 & 947 & 1015 & $7.2 \%$ \\
\hline Spain & 526 & 726 & 870 & 928 & 972 & $4.7 \%$ \\
\hline Thailand & 18 & 32 & 471 & 694 & 851 & $22.6 \%$ \\
\hline Taiwan & 71 & 137 & 493 & 679 & 764 & $12.5 \%$ \\
\hline Iran & 35 & 246 & 608 & 688 & 731 & $6.3 \%$ \\
\hline UK & 318 & 476 & 616 & 701 & 680 & $-3.0 \%$ \\
\hline Canada & 258 & 383 & 620 & 694 & 649 & $-6.5 \%$ \\
\hline Czech Rep. & 307 & 352 & 431 & 526 & 565 & $7.4 \%$ \\
\hline Turkey & 98 & 265 & 384 & 504 & 554 & $9.9 \%$ \\
\hline Poland & 77 & 191 & 297 & 392 & 436 & $11.2 \%$ \\
\hline Malaysia & 22 & 116 & 275 & 367 & 398 & $8.4 \%$ \\
\hline South Africa & 134 & 192 & 240 & 290 & 297 & $2.4 \%$ \\
\hline Hungary & 95 & 156 & 214 & 257 & 287 & $11.7 \%$ \\
\hline Argentina & 83 & 191 & 307 & 261 & 238 & $-8.8 \%$ \\
\hline Sweden & 21 & 70 & 156 & 207 & 236 & $14.0 \%$ \\
\hline Slovakia & 34 & 76 & 113 & 151 & 193 & $27.8 \%$ \\
\hline Austria & 77 & 133 & 158 & 188 & 192 & $2.1 \%$ \\
\hline Australia & 163 & 49 & 127 & 179 & 186 & $3.9 \%$ \\
\hline Romania & 4 & 6 & 115 & 155 & 181 & $16.8 \%$ \\
\hline Indonesia & 10 & 36 & 110 & 135 & 155 & $14.8 \%$ \\
\hline Portugal & 54 & 53 & 128 & 146 & 149 & $2.1 \%$ \\
\hline Belgium & 74 & 134 & 125 & 143 & 142 & $-0.7 \%$ \\
\hline Netherlands & 16 & 82 & 114 & 120 & 128 & $6.7 \%$ \\
\hline Russia & 5 & 16 & 42 & 78 & 106 & $35.9 \%$ \\
\hline Slovenia & 83 & 86 & 79 & 80 & 93 & $16.3 \%$ \\
\hline Egypt & 1 & 3 & 14 & 21 & 32 & $52.4 \%$ \\
\hline Finland & 2 & 18 & 32 & 29 & 32 & $10.3 \%$ \\
\hline Ukraine & 0 & 4 & 8 & 12 & 16 & $33.3 \%$ \\
\hline Serbia & 7 & 7 & 5 & 6 & 10 & $66.7 \%$ \\
\hline Uzbekistan & 0 & 0 & 0 & 2 & 4 & $100.0 \%$ \\
\hline
\end{tabular}

Japan, China, USA, and Germany manufactured respectively 16 per cent, 13 per cent, 12 per cent, and 9 per cent of total global commercial vehicles manufactured in 2008 (see Fig. 6). It is not a coincidence that the nations mentioned above are among those having the largest number of TS 169494 certificates issued (see Table 2). In general, the ranking of the most productive automotive countries much resembles the ranking based on the number of TS 16949 certificates. It is indeed expected that there is some relationship between the number of certificates and the actual automotive production. This relationship is highlighted in Fig. 7. The figure shows, on two different scales, the number of certificates issued (left scale) and the number of vehicles produced (right scale). Excluding few exceptions (such as Japan, Brazil, and Russia), there is evidence of a certain proportion among certificates and car production.

Figure 8 illustrates this relationship, suggesting a linear dependency between the two variables. Rather than proposing a dependency model, the goal of the figure is to highlight some particular cases, i.e. Japan, China, and US.

In Japan, major car manufacturers, although appreciating TS 16949 certification, do not make it a mandatory requirement for suppliers, preferring a specific and personalized approach with each of them. The result is that, even though Japan has recently shown considerable interest in the TS certification (growth of 7.5 per cent in 2008), the number of certificates is well below the global proportion. Considering the world average, also in the US there is disproportion between production and number of certificates issued, even though the US was one of the nations who first proposed the development of these new standards. An example is the famous Big Three (Ford, GM, and Chrysler) who have always demanded compliance with a number of specific standards. Thus, 


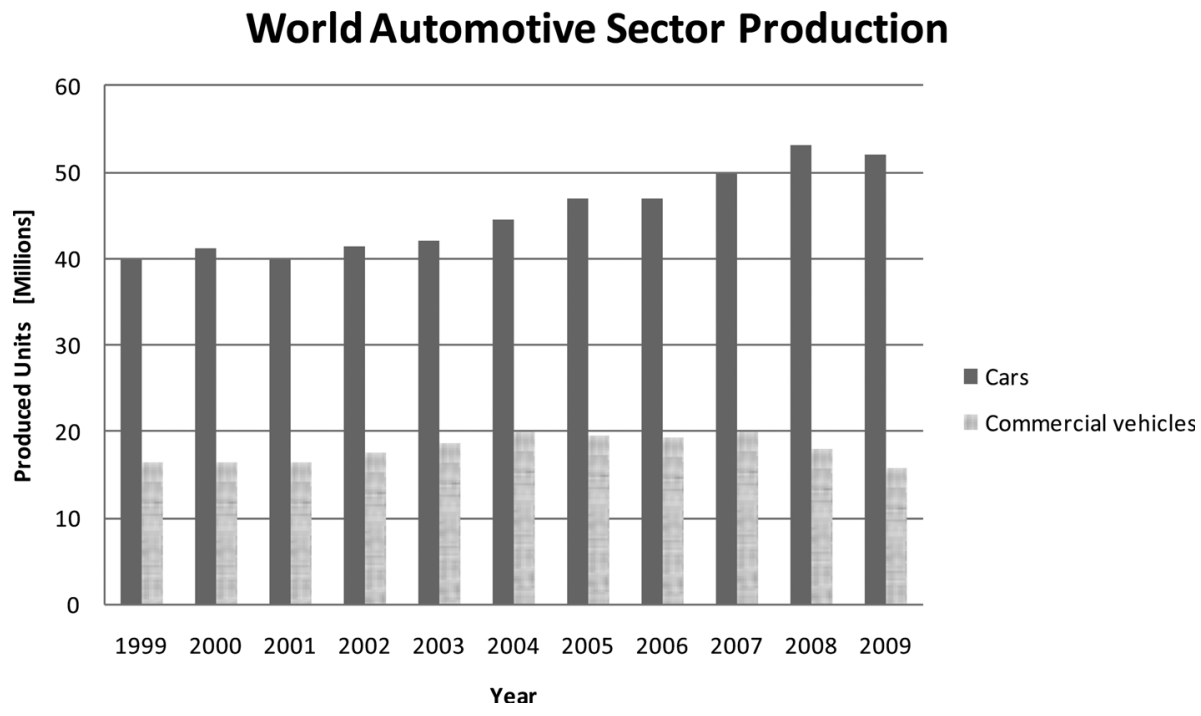

Fig. 5 Passenger cars and commercial vehicle production per year [39]

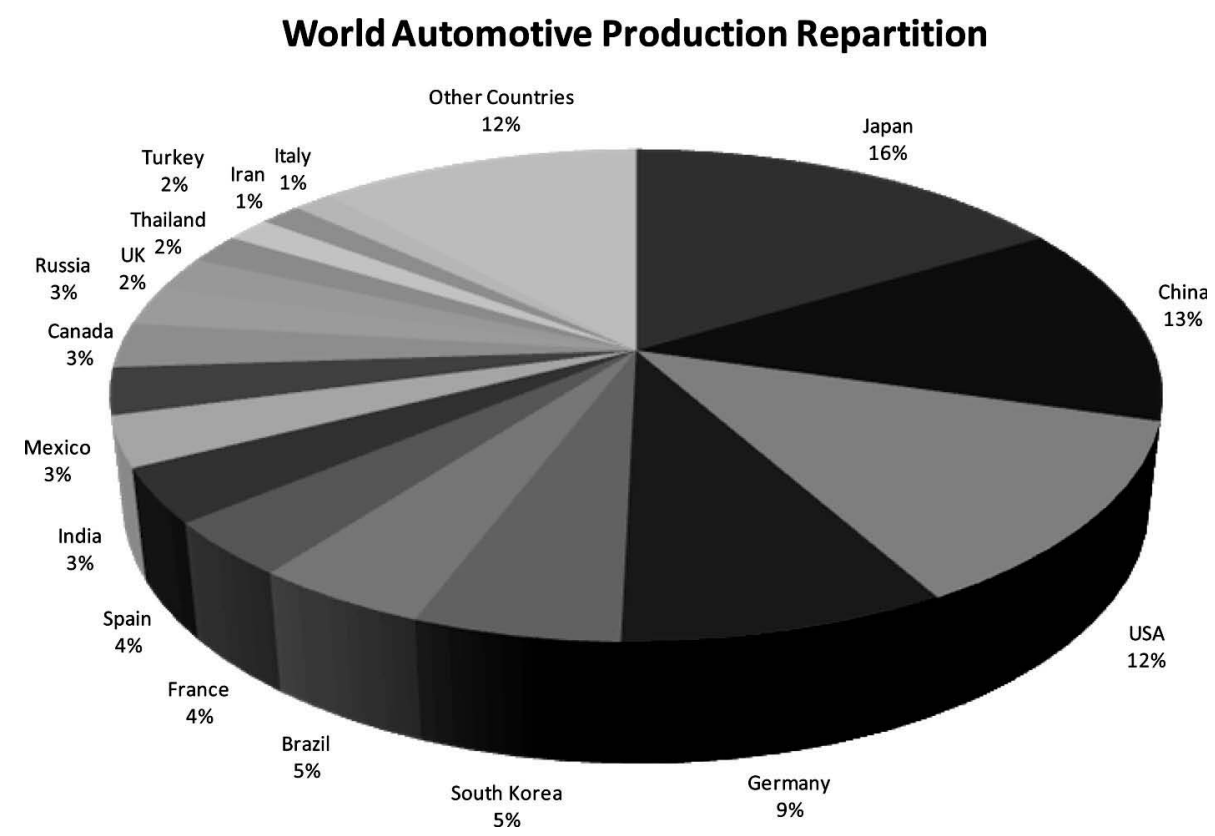

Fig. 6 World automotive production repartition in 2008 [39]

suppliers with multiple customers have willingly welcomed the publication of TS 16949. The others - who did not feel this need - remained tied to the old and specific standards that are still recognized by the manufacturers [28].

In China, the situation is diametrically opposite. China is the major fastest-growing economy in the world [31]. Also it is the largest trading nation and exporter, and the second largest importer of goods [31]. Low labour cost has made it probably one of the most appealing markets for end and semi-finished products. Thus, the relatively high ratio between TS 16949 certificates and produced vehicles is probably attributable to the presence of many automotive suppliers of semi-finished components and products. In this case, TS 16949 certification is seen and pursued as a necessary tool to deal with both national and international car manufacturers.

\subsection{GDP versus ISO/TS certification}

Building about 70 million vehicles per year produces a global business turnover of about $\$ 1.9$ trillion. The automotive industry employs more than 8 million people in making vehicles and components. In addition to these direct employees, another 50 million people are employed indirectly in related manufacturing and service provision (this represents over 36 per cent 
ISO/TS 16949 certificates vs Car Produced (Dec 2008)

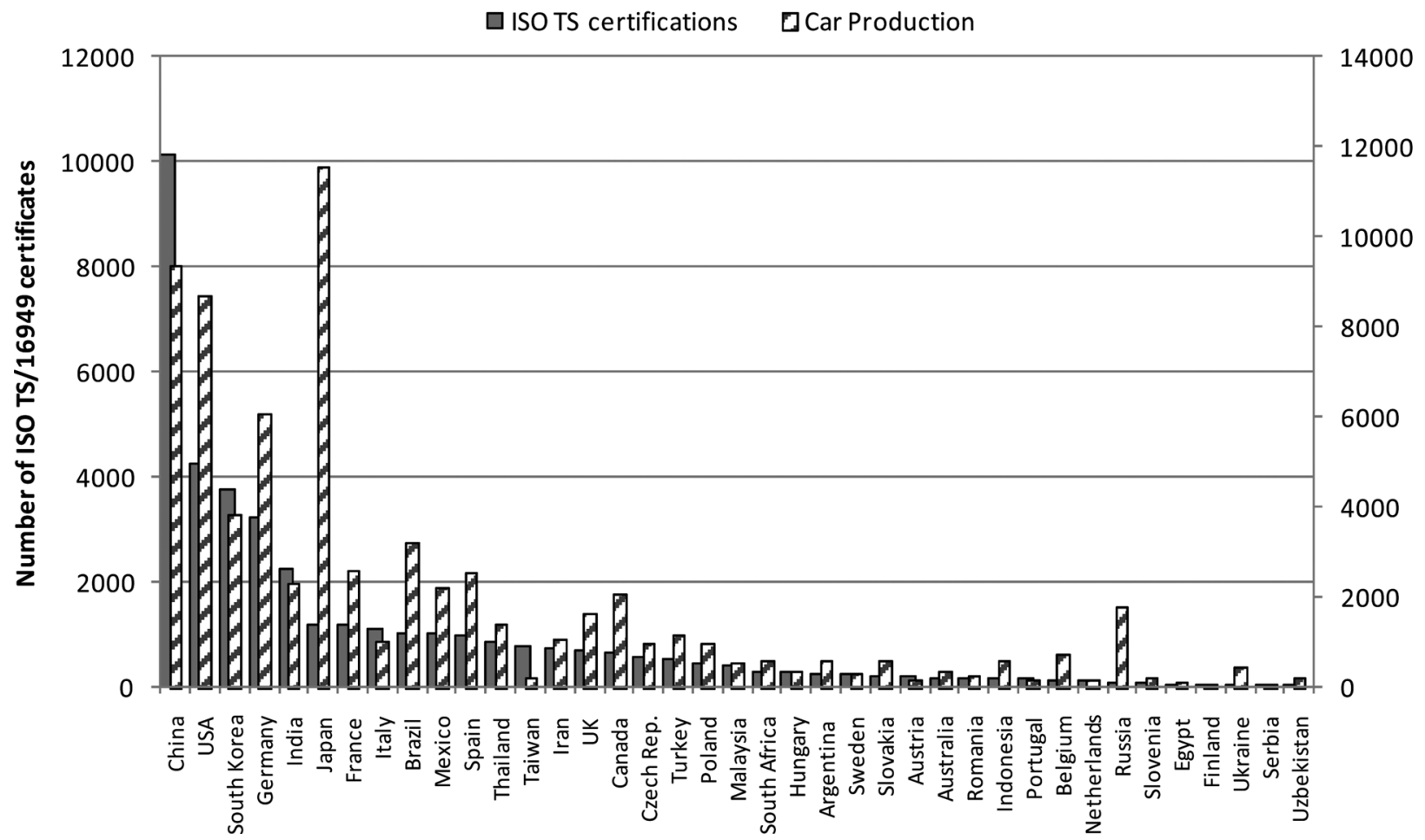

Fig. 7 Comparison between TS 16949 certificates and cars produced per country

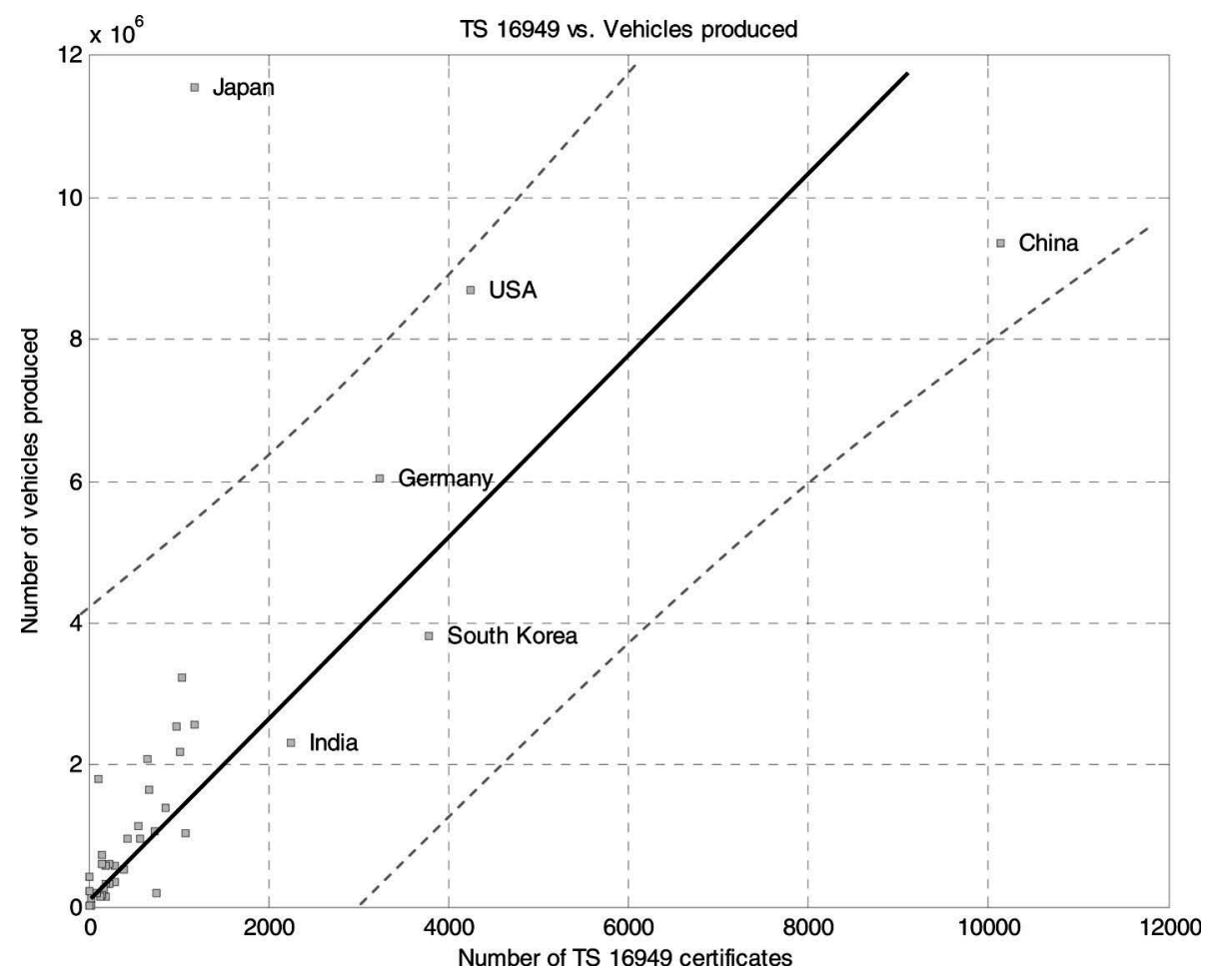

Fig. 8 TS 16949 certificates vs cars produced per country. Dotted lines represent the 95 per cent prediction interval (PI) 
Table 3 Correlation between GDP $\mathrm{pc}_{\mathrm{p}}$ and number of TS 16949 certificates. Nations with both correlation values greater than 0.9 are highlighted in bold. The period of analysis is from 2004 to 2008

\begin{tabular}{|c|c|c|c|c|}
\hline & $\begin{array}{l}\text { Correlation } \\
\text { between } \\
\text { GDP }_{\text {pc }} \text { and } \\
\text { no. of } \\
\text { TS } 16949\end{array}$ & $\begin{array}{l}\text { Correlation } \\
\text { between } \\
\text { GDP }_{\mathrm{pc}} \\
\text { and car } \\
\text { production }\end{array}$ & $\begin{array}{l}\text { Growth of } \\
\text { TS } \\
16949 \\
(2008)\end{array}$ & $\begin{array}{l}\text { Growth of } \\
\text { GDP pc } \\
(2008)\end{array}$ \\
\hline China & 0.98 & 0.96 & $31.2 \%$ & $27.3 \%$ \\
\hline USA & 0.91 & -0.83 & $-0.83 \%$ & $1.6 \%$ \\
\hline South Korea & 0.86 & 0.99 & $9.4 \%$ & -11.6 \\
\hline Germany & 0.80 & 0.82 & $5.7 \%$ & $10.5 \%$ \\
\hline India & 0.96 & 0.96 & $12.0 \%$ & $\mathbf{8 . 0 \%}$ \\
\hline Japan & 0.07 & -0.06 & $7.5 \%$ & $12.2 \%$ \\
\hline France & 0.70 & -0.97 & $1.5 \%$ & $9.8 \%$ \\
\hline Italy & 0.83 & -0.07 & $6.3 \%$ & $8.4 \%$ \\
\hline Brazil & 0.96 & 0.99 & $6.7 \%$ & $16.7 \%$ \\
\hline Mexico & 0.92 & 0.98 & $7.2 \%$ & $5.2 \%$ \\
\hline Spain & 0.89 & -0.68 & $4.7 \%$ & $9.2 \%$ \\
\hline Thailand & 0.98 & 0.96 & $22.6 \%$ & $10.0 \%$ \\
\hline Taiwan & 0.94 & -0.87 & $12.5 \%$ & $1.4 \%$ \\
\hline Iran & 0.89 & 0.99 & $6.3 \%$ & $15.3 \%$ \\
\hline UK & 0.91 & -0.57 & $-3.0 \%$ & $-4.8 \%$ \\
\hline Canada & 0.95 & -0.77 & $-6.5 \%$ & $3.9 \%$ \\
\hline Czech Rep. & 0.97 & 0.86 & $7.4 \%$ & $23.0 \%$ \\
\hline Turkey & 0.97 & 0.99 & $9.9 \%$ & $11.2 \%$ \\
\hline Poland & 0.94 & 0.99 & $11.2 \%$ & $24.1 \%$ \\
\hline Malaysia & 0.93 & -0.02 & $8.4 \%$ & $17.1 \%$ \\
\hline
\end{tabular}

of the world's total manufacturing employment). The automobile industry is also a very important innovator sector, investing about $\$ 85$ billion in research, development, and production [39]. In other words, the global automotive industry is a key sector of the major economies in the world. For this reason, in order to understand the effects of TS 16949 certification on the different national economies, this section compares the national GDP per capita $\left(\mathrm{GDP}_{\mathrm{pc}}\right)$ with the number of certificates.

Although results can be easily generalized, the analysis is limited to the first 20 nations in terms of issued certificates. Table 3 shows the correlations between $\mathrm{GDP}_{\mathrm{pc}}$, car production and number of ISO TS 16949 certificates. Note that both correlation values are very high ( $>0.9)$ for developing and emerging countries. In particular, India, Brazil, China, Thailand, Turkey, and Poland are countries where car makers have heavily invested and whose economies are currently tied to automotive production (high correlation between $\mathrm{GDP}_{\mathrm{pc}}$ and production).

On the other hand, the countries with low or even negative correlation between $\mathrm{GDP}_{\mathrm{pc}}$ and car production are those where car makers have gradually limited investments by progressively reducing production. Generally, these countries have a sound economy, with high cost of labour.

The most interesting result that emerges from this analysis is undoubtedly the high correlation between $\mathrm{GDP}_{\mathrm{pc}}$ and the number of TS 16949 certificates.
However, this result has to be carefully interpreted since the correlation value cannot be used to infer a causal relationship between variables $[40,41]$.

According to the results presented above, it is difficult to determine whether the certification has had positive effects on different national economies or, conversely, the development of national economies has positively influenced the number of certifications issued. Certainly if there is any relationship between the two trends, it is a positive relationship. Generally speaking a sound national economy may have prompted companies to achieve the certification and, on the other hand, the certification itself may have improved production processes so as significantly to affect the economic results of the companies involved.

\section{CONCLUSIONS}

Quality certifications and their evolution over time are research topics arousing great interest [30]. Up to now, however, few works have directly dealt with ISO/TS 16949. For this reason the present work aimed to provide an initial analysis of this type of certification a few years after its launch.

TS 16949 was recently created to meet a pressing need of suppliers to car manufacturers who had to deal with specific standards. The success of the standard was immediate since its early introduction. Up to the end of December 2008, almost 40000 ISO/TS 16949 certificates had been issued in 81 countries and economies. Against the backdrop of a general economic crisis that has significantly affected the automotive sector, the certification market did not seem to suffer particularly. Also, the predictive models developed and proposed in the literature for other types of standards, suggest that there is still room for further growth.

The reason for this success must be sought in the causes that have prompted companies to achieve the certification. Quality certifications are indeed perceived as an advertising tool, as an instrument for internal improvement, but also as a necessary tool for doing business with car manufacturers. The analysis presented in this paper showed how the diffusion of the TS 16949 certification was significantly more pronounced in those countries where car manufacturers require it.

Future research analysis can be addressed towards the study of the effects of the certification from a micro-economic point of view, considering - for instance - the evolution of internal business indicators for a significant sample of companies. Another future interesting research topic is the analysis of the companies' reaction to the current economic crisis. 
Will companies keep trying to find the solution to the crisis in the quality certification system?

(C) Authors 2011

\section{REFERENCES}

1 Casper, S. and Hancké, B. Global quality norms with national production regimes: ISO 9000 standards in the French and German car industries. Orgn Studies, 1999, 20(6), 961-985.

2 Mendel, P. J. International standardization and global governance: the spread of quality and environmental management standards. In Organizations, policy and the natural environment: Institutional and strategic perspectives (Eds A. J. Hoffman and M. J. Ventresca), 2002, pp. 407-424 (Stanford, Stanford University Press).

3 Franceschini, F., Galetto, M., and Cecconi, P. A worldwide analysis of ISO 9000 standard diffusion. Benchmarking: An Int. J., 2006, 13(4), 523-541.

4 Clougherty, J. A. and Grajek, M. The impact of ISO 9000 diffusion on trade and FDI: A new institutional analysis. J. Int. Bus. Studies, 2008, 39, 613-633.

5 ISO The ISO survey of ISO 9000 and ISO 14000 Certificates. Eighteenth cycle, 2009 (International Organization for Standardization, Geneva).

6 ISO ISO/TS Technical Specification, 2009 (International Organization for Standardization, Geneva).

7 Corbett, C. J. Global diffusion of ISO9000 certification through supply chains. Mfg Service Oper. Mgmt, 2006, 8(4), 330-350.

8 Guler, I., Guillen, M. F., and Macpherson, J. M. Global competition, institutions, and the diffusion of organizational practices: the international spread of ISO 9000 quality certificates. Adm. Sci. Q., 2002, 47(2), 207-232.

9 Langnera, B. and Seidel, V. P. Collaborative concept development using supplier competitions: insights from the automotive industry. J. Engng Technol. Mgmnt, 2009, 26(1-2), 1-14.

10 Franceschini, F., Galetto, M., Maisano, D., and Mastrogiacomo, L. A proposal of a new paradigm for national Quality Certification Systems. Int. J. Qual. Reliability Mgmnt, 2010, 28(4).

11 Guerin, J. M. and Rice, R. W. Perceptions of importers in the United Kingdom, Germany, and the Netherlands regarding the competitive advantage of ISO 9000. Forest Products J., 1996, 46(4), 27-31.

12 Conti, T. Vision 2000: positioning the new ISO 9000 standards with respect to total quality management models. Total Qual. Mgmnt, 1999, 10, 454-464.

13 Terlaak, A. and King, A. A. The effect of certification with the ISO 9000 quality management standard: a signaling approach. J. Economic Behavior and Organization, 2006, 60(4), 579-602.

14 Dissanayaka, S. M., Kumarsawamy, M. M., Karim, K., and Marosszeky, M. Evaluating outcomes from ISO 9000 certified quality systems of Hong Kong constructors. Total Qual. Mgmnt, 2001, 12(1), 29-40.

15 Hayes, H. M. ISO 9000: the new strategic consideration. Bus. Horizons, 1994, 37(3), 52-60.

16 Terziovski, M., Power, D., and Sohal, A. The longitudinal effects of the ISO 9000 certification process on business performance. Eur. J. Opl Res., 2003, 146(3), 580-595.

17 Gupta, A. Quality management practices of ISO vs nonISO companies: a case of Indian industry. Ind. Mgmnt Data Systems, 2000, 100(9), 451-455.

18 Terziovski, M. and Samson, D. The link between total quality management practice and organisational performance. Int. J. Qual. Reliability Mgmnt, 1999, 16(3), 226-237.

19 Dick, G., Gallimore, K., and Brown, J. Does ISO 9000 accreditation make a profound difference to the way service quality is perceived and measured? Managing Service Qual., 2002, 12(1), 30-42.

20 Ozgur, C., Meek, G., and Toker, A. The impact of ISO certification on the levels of awareness and usage of quality tools and concepts: a survey of Turkish manufacturing companies. Qual. MgmtJ., 2002, 9(2), 57-69.

21 Tarì, J. and Molina, J. Quality management results in ISO 9000 certified Spanish firms. The TQM Mag., 2002, 14(4), 232-239.

22 Tarì, J. and Sabater, V. Quality tools and techniques: are they necessary for quality management? Int. J. Prod. Economics, 2004, 92, 267-280.

23 Quazi, H. and Jacobs, R. Impact of ISO 9000 certification on training and development activities. Int. J. Qual. Reliability Mgmnt, 2004, 21(5), 497-517.

24 Pekovic, S. and Galia, G. From quality to innovation: evidence from two French Employer Surveys. Technovation, 2009, 29, 829-842.

25 Escanciano, C., Esteban Fernández, E., and Vázquez, C. Linking the firm's technological status and ISO 9000 certification: results of an empirical research. Technovation, 2002, 22(8), 509-515.

26 Romano, P. ISO 9000: what is its impact on performance? Qual. Mgmnt J., 2000, 7(3), 38-56.

27 IATF, available from http://www.iatfglobaloversight.org/ (accessed 14 April 2010).

28 Reid, R. D. TS 16949 - where did it come from? Qual. Prog., 2005, 38(3), 31-38.

29 Franceschini, F., Galetto, M., and Giannì, G. A new forecasting model for the diffusion of ISO 9000 standard certifications in European countries. Int. J. Qual. Reliability Mgmnt, 2004, 21 (1), 32-50.

30 Sampaio, P., Saraiva, P., and Guimaraes Rodrigues, A. ISO 9001 certification research: questions, answers and approaches. Int. J. Qual. Reliability Mgmnt, 2009, 26(1), 38-58.

31 IMF, available from http://www.imf.org/external/ns/cs. aspx?id=28 (accessed 14 April 2010).

32 Verhuls, P. Notice sur la loi que la population poursuit dans son accroissement. Correspondance Mathématique et Physique, 1838, 10, 113-121.

33 Stoneman, P. Handbook of the economics of innovation and technological change, 1995 (Blackwell Handbooks in Economics, Oxford).

34 Toyota, available from http://www.toyota.com/ (accessed 14 April 2010).

35 Ford, available from http://www.ford.com/ (accessed 14 April 2010).

36 GM, available from http://www.gm.com/ (accessed 14 April 2010). 
37 FIAT, available from http://www.fiatgroup.com/ (accessed 14 April 2010).

38 Franceschini, F., Galetto, M., Maisano, D., and Mastrogiacomo, L. Clustering of European countries based on ISO 9000 certification diffusion. Int. J. Qual. Reliability Mgmnt, 2010, 27(5), 558-575.

39 OICA, available from http://oica.net/category/productionstatistics/ (accessed 14 April 2010).
40 Franceschini F., Galetto, M., and Maisano, D. Management by measurements: designing key indicators and performance measurement systems, 2007 (Springer Verlag, Berlin).

41 Montgomery, D. C. Statistical quality control, a modern introduction, 6th edition, 2009 (John Wiley, New York). 